\title{
PERAN DAN FUNGSI PARTAI POLITIK DI INDONESIA DITINJAU DARI UNDANG-UNDANG NOMOR 2 TAHUN 2011
}

\author{
Abraham Ferry Rosando \\ Universitas Katolik Darma Cendika
}

\begin{abstract}
ABSTRAK
Partisipasi rakyat dalam menyelenggarakan pemerintahan pada negara demokrasi secara positif ditentukan dalam peraturan perundang-undangan yang berarti bahwa aturan permainan dalam kehidupan demokrasi diatur secara kelembagaan. Hal ini berarti bahwa keinginan-keinginan rakyat dalam memerintah suatu negara disalurkan melalui lembaga-lembaga perwakilan yang ada, yang dibentuk melalui pemilihan umum yang demokrasi. Partai politik dalam sistem pemerintahan demokrasi di Indonesia sangat berperan, karena salah satu fungsi dari partai politik sebagaimana Pasal 11 Undang-Undang Nomor 2 Tahun 2008 Tentang Partai Politik yaitu memberikan pendidikan politik bagi anggota dan masyarakat luas agar menjadi warga negara Indonesia yang sadar akan hak dan kewajibannya dalam kehidupan bermasyarakat, berbangsa, dan bernegara; dan penyerap, penghimpun, dan penyalur aspirasi politik masyarakat dalam merumuskan dan menetapkan kebijakan negara; partisipasi politik warga negara Indonesia.
\end{abstract}

Kata kunci: demonstrasi, partai politik, aspirasi rakyat

\begin{abstract}
People's participation in running the government in a democracy is positively defined in the legislation, which means that the rules of the democracy regulated on institutions. This means that the desires of the people in governing a country are channeled through representative institutions there, which was formed through democratic elections. Political parties in a democratic system of government in Indonesia was crucial, as a function of the political parties as well as Article 11 of Law No. 2 Year 2008 on Political Parties which provide political education for members and the public to become Indonesian citizens who are aware of their rights and obligations in the life of society, nation, and state, and absorbent, gathering and channeling the political aspirations of the community in formulating and determining state policy; political participation of citizens in Indonesia.
\end{abstract}

Keywords: demonstrations, political parties, people's aspirations 


\section{A. PENDAHULUAN}

Partisipasi rakyat dalam menyelenggarakan pemerintahan pada negara demokrasi secara positif ditentukan dalam peraturan perundang-undangan yang berarti bahwa aturan permainan dalam kehidupan demokrasi diatur secara kelembagaan. Hal ini berarti bahwa keinginan-keinginan rakyat dalam memerintah suatu negara disalurkan melalui lembaga-lembaga perwakilan yang ada, yang dibentuk melalui pemilihan umum yang demokrasi.

Dalam kaitannya dengan demokrasi dalam mengeluarkan pendapat, tidak dilakukan secara bebas, melainkan harus disertai dengan tanggung jawab yang besar atas kebebasan tersebut. Masalah pembagian kekuasaan adalah masalah yang selalu dihubungkan dengan ajaran Montesquieu yang terkenal dengan sebutan Trias Politica.

Pengertian pembagian kekuasaan berbeda dengan pemisahan kekuasaan. Pemisahan kekuasaan berarti bahwa kekuasaan negara dipisah-pisah dalam beberapa bagian, baik mengenai orangnya maupun mengenai fungsinya. Pemisahan kekuasaan yang murni tidak dapat dilaksanakan, karena itu pilihan jatuh kepada istilah pembagian kekuasaan yang berarti bahwa kekuasaan itu memang dibagi-bagi dalam beberapa bagian, tetapi tidak dipisahkan, sehingga di antara bagian-bagian itu dimungkinkan adanya kerjasama.

Dikaitkan dengan sistem pemerintahan demokrasi, seluruh rakyat ikut menjalankan pemerintahan, namun dengan atau melalui perwakilan yang duduk di parlemen yaitu Dewan Perwakilan Rakyat. Sebagai wakil rakyat, Dewan Perwakilan Rakyat merupakan penyalur aspirasi rakyat yang diwakilinya melalui pemilihan secara langsung anggota dengan diusung oleh Partai Politik. Kenyataan yang terjadi, aspirasi rakyat yang tidak tersalurkan upaya selanjutnya yaitu mengadakan demonstrasi yang ditujukan kepada pemerintah. 


\section{B. DEMONSTRASI SEBAGAI HAK WARGA NEGARA}

Demonstrasi merupakan sebuah gerakan protes yang dilakukan sekumpulan massa di depan khalayak umum. Demonstrasi biasanya dilakukan untuk menyuarakan aspirasi dari suatu kelompok tertentu sebagai sebuah upaya penekanan secara politik. Berpijak dari pengertian demonstrasi yaitu protes dan dilakukan untuk menentang kebijakan. Protes dengan menyuarakan pendapat yang isinya menentang kebijakan merupakan hak setiap warga negara, yang berarti bahwa demonstrasi merupakan hak setiap warga negara yang oleh undang-undang dilindungi sebagaimana Pasal 28 UUD 1945 bahwa "kemerdekaan berserikat dan berkumpul, mengeluarkan pikiran dengan lisan dan tulisan dan sebagainya ditetapkan dengan undang-undang”. Ditindak lanjuti oleh diundangkannya UU No. 39 Tahun 1999.

Hak asasi manusia menurut Pasal 1 angka 1 Undang-Undang Nomor 39 Tahun 1999 adalah sebagai berikut:

Hak asasi manusia adalah seperangkat hak yang melekat pada hakikat dan keberadaan manusia sebagai makhluk Tuhan Yang Maha Esa dan merupakan anugerah-Nya yang wajib dihormati, dijunjung tinggi dan dilindungi oleh negara, hukum, pemerintah dan setiap orang demi kehormatan serta perlindungan harkat dan martabat manusia.

Hal ini berarti bahwa setiap orang mempunyai hak, dan hak tersebut melekat pada diri yang merupakan anugerah Tuhan Yang Maha Esa. Sebagai suatu hak, maka setiap orang wajib menghormati dan menjunjung tinggi atas hak tersebut, yang oleh negara dilindungi. Oleh karena itu berarti bahwa "hak-hak yang dimiliki manusia berdasarkan martabatnya sebagai manusia dan bukan karena pemberian masyarakat atau negara disebut hak asasi manusia".

1 Jadi hak asasi manusia itu bukan merupakan suatu hak yang dibuat, melainkan hak yang melekat pada diri setiap orang sebagai warga masyarakat. Hak-hak yang dimiliki manusia sebagaimana dikemukakan oleh Eko Sugitario berdasarkan martabatnya sebagai manusia dan bukan karena pemberian masyarakat atau negara disebut hak asasi manusia. Hak asasi manusia dan negara

${ }^{1}$ Eko Sugitario, Implementasi Hak Kodrat dalam Hukum Positif Hak-hak Asasi Manusia Di Negara Hukum, Disampaikan Pada Rapat Terbuka Sernat Universitas Surabaya, 19 Juli 2003, hlm. 25 . 
hukum tidak dapat dipisahkan, justru berpikir secara berkaitan ide bagaimana keadilan dan ketertiban dapat terwujud. Dengan demikian pengakuan dan pengukuhan negara hukum salah satu tujuannya melindungi hak asasi manusia, berarti hak dan sekaligus kemerdekaan atau kebebasan perorangan diakui, dihormati dan dijunjung tinggi. Pengakuan dan perlidungan terhadap hak asasi manusia mendapat tempat utama dan dapat dikatakan sebagai tujuan dari negara hukum. $^{2}$ Hak asasi manusia merupakan hak dasar yang secara kodrat melekat pada diri manusia, bersifat universal dan langgeng, sehingga perlu dilindungi, dihormati, dipertahankan dan tidak boleh diabaikan, dikurangi, serta dirampas oleh siapapun juga. Hak asasi manusia yang berkaitan dengan derajat dan martabat manusia harus mendapat pengakuan dan penghargaan dalam praktik kehidupan berbangsa. Pengakuan dan penghargaan terhadap hak asasi manusia dalam praktik kehidupan berbangsa diwujudkan dalam hukum positif di berbagai negara yang mengaku sebagai negara hukum. ${ }^{3}$

Sehubungan dengan perlunya menghormati hak asasi manusia seseorang warga negara, merupakan suatu perwujudan dari Indonesia adalah negara yang berdasarkan atas hukum, bukan didasarkan atas kekuasaan belaka. Hal ini dipertegas oleh Masyhur Effendi yang mengemukakan bahwa hak asasi manusia dengan negara hukum tidak dapat dipisahkan, justru berpikir secara hukum berkaitan dengan ide bagaimana keadilan dan ketertiban dapat terwujud. Dengan demikian, pengakuan dan pengukuhan negara hukum salah satu tujuannya melindungi hak asasi manusia, berarti hak dan sekaligus kebebasan perseorangan diakui, dihormati dan dijunjung tinggi. ${ }^{4}$

Menurut Friedrich Julius Stahl dikutip dari buku karya Eko Sugitario ada empat unsur negara hukum dalam arti klasik, yaitu:

1) Hak-hak manusia;

2) Pemisahan atau pembagian kekuasaan untuk menjamin hak-hak itu (di negara-negara Eropa Kontinental biasa disebut trias politika);

\footnotetext{
${ }^{2}$ Ibid., hlm. 2

${ }^{3}$ Ibid.

${ }^{4}$ Masyhur Effendi, Hak Asasi Manusia Dalam Hukum Nasional dan Internasional, Jakarta: Ghalia Indonesia, 1994, hlm. 27.
} 
3) Pemerintah berdasarkan peraturan perundang-undangan;

4) Peradilan administrasi dalam perselisihan. ${ }^{5}$

Hak asasi merupakan hak dasar yang melekat pada diri setiap orang. Sebagai hak dasar, maka telah tepat jika hak-hak tersebut diatur dalam Undang-Undang Dasar 1945. Hak asasi yang berhubungan dengan harta benda diatur dalam Pasal 28 G ayat (1) Undang-undang Dasar 1945, yang menentukan: "Setiap orang berhak atas perlindungan diri pribadi, keluarga, kehormatan, martabat dan harta benda yang di bawah kekuasaannya, serta berhak atas rasa aman dan perlindungan dari ancaman ketakutan untuk berbuat atau tidak berbuat sesuatu yang merupakan hak asasi". Hal ini menunjukkan bahwa hak asasi manusia tidak dapat dipisahkan dari Undang-Undang Dasar 1945, sesuai dengan yang dikemukakan oleh Soedjono Dirdjosisworo sebagai berikut:

a. hak asasi manusia adalah tidak bertentangan dengan Undang-Undang Dasar 1945 dan Pancasila, bahkan kelahiran Republik Indonesia adalah berdasarkan pengakuan hak-hak asasi manusia, seperti dinyatakan dalam Pembukaan Undang-Undang Dasar 1945;

b. hak asasi manusia adalah tidak terpisahkan dengan dan merupakan perlindungan terhadap nilai martabat manusia, sehingga oleh sebab itu harus dijunjung tinggi oleh bangsa dan negara Republik Indonesia yang berfalsafah Pancasila. ${ }^{6}$

Hak yang dilindungi dan termasuk perlindungan hak asasi yaitu hak seseorang untuk memilih dan dipilih dalam Pemilihan Umum. Hal ini sesuai dengan ketentuan Pasal 43 UU No. 39 Tahun 1999, yang menentukan sebagai berikut:

1. Setiap warga negara berhak untuk dipilih dan memilih dalam pemilihan umum berdasarkan persamaan hak melalui pemungutan suara yang

\footnotetext{
${ }^{5}$ Eko Sugitario, Op. cit., hlm. 26.

${ }^{6}$ Soedjono Dirdjosisworo, Pengadilan Hak Asasi Manusia Indonesia, Bandung: Citra Aditya Bakti, 2002, hlm. 20.
} 
langsung, umum, bebas, rahasia, jujur dan adil sesuai dengan ketentuan peraturan perundang-undangan.

2. Setiap warga negara berhak turut serta dalam pemerintahan dengan langsung atau dengan perantaraan wakil yang dipilihnya dengan bebas, menurut cara yang ditentukan dalam peraturan perundang-undangan.

Hal ini berarti bahwa setiap warga negara mempunyai hak untuk memilih dan dipilih dalam pemilihan umum. Sebagai hak tentunya juga mempunyai hak untuk tidak menggunakan hak atau menolak untuk dipilih dan tidak menggunakan haknya untuk memilih.

Sebagaimana disebutkan dalam uraian sebelumnya bahwa hak asasi merupakan hak dasar dari setiap manusia. Meskipun demikian seseorang tidak diperkenankan melakukan perbuatan dengan berdasar pada pelaksanaan hak berakibat terjadinya pelanggaran hukum. Sebagaimana ditentukan dalam 67 UU No. 39 Tahun 1999, sebagai berikut: "Setiap orang yang ada di wilayah negara Republik Indonesia wajib patuh pada peraturan perundang-undangan, hukum tak tertulis, dan hukum internasional mengenai hak asasi manusia yang telah diterima oleh negara Republik Indonesia”. Dengan demikian dalam menggunakan haknya tersebut tidak boleh bertentangan dengan peraturan perundang-undangan.

Selain tidak boleh bertentangan dengan undang-undang, dalam menjalankan haknya tidak boleh melanggar hak orang lain, sesuai dengan yang dimaksud oleh Pasal 69 UU No. 39 Tahun 1999, yang menentukan sebagai berikut:

1. Setiap warga negara wajib menghormati hak asasi manusia orang lain, moral, etika dan tata tertib kehidupan bermasyarakat, berbangsa dan bernegara.

2. Setiap hak asasi manusia seseorang menimbulkan kewajiban dasar dan tanggung jawab untuk menghormati hak asasi orang lain secara timbal balik serta menjadi tugas Pemerintah untuk menghormati, melindungi, menegakkan, dan memajukannya. 
Hal ini berarti bahwa seseorang tidak boleh memaksakan kehendaknya pada orang lain, karena memaksakan kehendaknya kepada orang lain dapat dikatakan sebagai telah melakukan perbuatan yang tidak menghormati hak asasi manusia orang lain, moral, etika dan tata tertib kehidupan bermasyarakat, berbangsa dan bernegara, yang merupakan kewajiban dasar dan tanggung jawab untuk menghormati hak asasi orang lain secara timbal balik serta menjadi tugas Pemerintah untuk menghormati, melindungi, menegakkan, dan memajukannya.

Setiap orang dalam menggunakan haknya, tidak seorangpun boleh merampas dalam arti mengambil hak tersebut secara sewenang-wenang, meskipun demikian dalam menggunakan haknya tersebut harus memperhatikan kepentingan sosial atau masyarakat sekelilingnya. Selain itu penggunaan hak asasi juga harus memperhatikan atau menghormati hak orang lain serta wajib tunduk pada pembatasan sebagaimana ditetapkan oleh peraturan perundang-undangan sebagaimana ditentukan dalam Pasal 70 UU No. 39 Tahun 1999 sebagai berikut:

Dalam menjalankan hak dan kebebasannya, setiap orang wajib untuk tunduk kepada pembatasan yang ditetapkan oleh undang-undang dengan maksud untuk menjamin pengakuan serta penghormatan atas hak dan kebebasan orang lain dan untuk memenuhi tuntutan yang adil sesuai dengan pertimbangan moral, keamanan dan ketertiban umum dalam suatu masyarakat demokratis.

Kebebasan dalam arti kemerdekaan antara lain:

a. kemerdekaan berpikir dan mengeluarkan pikiran serta menganut keyakinannya sendiri;

b. kemerdekaan untuk bersatu dengan teman-teman yang paham serta mempunyai tujuan-tujuan tertentu. Ini merupakan kemerdekaan untuk berkumpul dan bersidang;

c. kemerdekaan untuk mengatur penghidupan sendiri tidak seperti yang diperintahkan oleh kekuasaan yang berada di atasnya. ${ }^{7}$

\footnotetext{
${ }^{7}$ Bambang Sunggono dan Aries Hartanto, Bantuan Hukum dan Hak Asasi Manusia, Bandung : Mandar Maju, 2001, hlm. 74.
} 
Hal ini berarti bahwa setiap orang mempunyai hak untuk berpikir dan mengeluarkan pendapat, hak untuk bersatu dengan sesamanya yang seideologi dan tujuan yang sama, hak untuk berkumpul dan bersidang dan hak lainnya yang dijamin oleh undang-undang.

Sehubungan dengan hak-hak khususnya hak perorangan, dikemukakan sebagai berikut:

1) kemampuan pribadi harus dijamin;

2) tidak ada hak-hak fundamental yang ditafsirkan dengan tujuan dan meniadakan hak-hak fundamental itu;

3) setiap orang harus dijamin kebebasan menyatakan pendapatnya melalui semua media komunikasi terutama pers;

4) kehidupan pribadi orang haruslah tidak dapat dilanggar, rahasia surat menyurang haruslah dijamin;

5) kebebasan beragama haruslah dijamin;

6) hak untuk mendapatkan pengajaran haruslah dijamin kepada semua orang tanpa adanya diskriminatif;

7) setiap orang berhak untuk bebebasan berkumpul dan berserikat secara damai dan terutama untuk menjadi anggota dari suatu partai politik yang dipilihnya sendiri. ${ }^{8}$

Mengambil hak seseorang secara sewenang-wenang berarti telah melakukan perbuatan melanggar hak asasi manusia. Pasal 1 angka 6 Undang-Undang Nomor 39 Tahun 1999 menentukan:

Pelanggaran hak asasi manusia adalah setiap perbuatan seseorang atau kelompok orang termasuk aparat negara baik disengaja maupun tidak disengaja atau kelalaian yang secara melawan hukum mengurangi, menghalangi, membatasi dan atau mencabut hak asasi manusia seseorang atau kelompok orang yang dijamin oleh undang-undang ini dan tidak mendapatkan atau dikawatirkan tidak akan memperoleh penyelesaian hukum yang adil dan benar, berdasarkan mekanisme hukum yang berlaku.

${ }^{8}$ Ibid., hlm. 78 . 
Dengan memperhatikan ketentuan Pasal 1 angka 6 Undang-undang Nomor 39 Tahun 1999 di atas dapat dijelaskan bahwa melanggar hak asasi adalah apabila melakukan perbuatan yang mengurangi, menghalangi, membatasi dan atau mencabut hak asasi manusia seseorang atau kelompok orang yang dijamin oleh undang-undang ini dan tidak mendapatkan atau dikawatirkan tidak akan memperoleh penyelesaian hukum yang adil dan benar, berdasarkan mekanisme hukum yang berlaku. Undang-undang hak asasi manusia ini adalah merupakan payung dari seluruh peraturan perundang-undangan tentang hak asasi manusia. Oleh karena itu pelanggaran baik langsung maupun tidak langsung atas hak asasi manusia dikenakan sanksi pidana, perdata atau administrasi sesuai dengan ketentuan peraturan perundang-undangan.

Sebagai payung, maka UU No. 39 tahun 1999 dimaksudkan untuk memayungi seluruh peraturan perundang-undangan yang mengatur hak asasi manusia. Oleh karena sebagai payung dari peraturan perundang-undangan yang lain, maka diharapkan dapat memayungi peraturan perundang-undangan yang lain yang mengatur mengenai hak asasi manusia.

Dengan demikian, kepada siapapun juga baik orang perseorangan, golongan maupun aparat negara yang melakukan suatu tindakan dengan maksud menghalang-halangi hak asasi manusia adalah dilarang dan dapat dikatakan telah melanggar hak asasi manusia, kecuali dijalankan sesuai dengan peraturan perundang-undangan yang memberikan batasan penggunaan hak asasi manusia sebebas-bebasnya.

Dengan didasarkan uraian di atas, maka dapat dijelaskan bahwa seseorang dapat dikatakan melanggar hak asasi manusia yaitu baik disengaja maupun tidak disengaja atau kelalaian yang secara melawan hukum mengurangi, menghalangi, membatasi dan atau mencabut hak asasi manusia seseorang atau kelompok orang yang dijamin oleh undang-undang ini dan tidak mendapatkan atau dikawatirkan tidak akan memperoleh penyelesaian hukum yang adil dan benar, berdasarkan mekanisme hukum yang berlaku. Sebagai negara hukum, hak asasi manusia memperoleh perlindungan hukum di segala bidang. 
Abraham Ferry Rosando, Peran dan Fungsi Partai ...

\section{PERAN PARTAI POLITIK}

Partai politik menurut Undang-Undang Republik Indonesia Nomor 2 Tahun 2008 Tentang Partai Politik yang telah dirubah oleh Undang-Undang Republik Indonesia Nomor 2 Tahun 2011 Tentang Perubahan Atas Undang-Undang Nomor 2 Tahun 2008 Tentang Partai Politik (UU Parpol), adalah organisasi yang bersifat nasional dan dibentuk oleh sekelompok warga negara Indonesia secara sukarela atas dasar kesamaan kehendak dan cita-cita untuk memperjuangkan dan membela kepentingan politik anggota, masyarakat, bangsa dan negara, serta memelihara keutuhan Negara Kesatuan Republik Indonesia berdasarkan Pancasila dan Undang-Undang Dasar Negara Republik Indonesia Tahun 1945.

Di dalam dalam kehidupan politik modern yang demokratis, partai politik merupakan keharusan. Sebagai suatu organisasi, partai politik secara ideal dimaksudkan untuk mengaktifkan dan memobilitasi rakyat, mewakili kepentingan tertentu, memberikan jalan kompromi bagi pendapat yang saling bersaing, serta menyediakan sarana seksesi kepemimpinan politik secara absah (ligitimate) dan damai. Karena itu, partai politik dalam pengertian modern dapat didefinisikan sebagai suatu kelompok yang mengajukan calon-calon bagi jabatan publik untuk dipilih oleh rakyat sehingga dapat mengontrol atau mempengaruhi tindakantindakan pemerintah. ${ }^{9}$

Awal munculnya partai politik tidak lepas dari hakikat masyarakat di suatu negara dibagi menjadi dua bagian, yaitu infrastruktur dan supra struktur. Infrastruktur terdiri atas berbagai macam organisasi sosial, organisasi masyarakat, organisasi politik, organisasi keagamaan, para tokoh masyarakat dan lain-lain organisasi. Dalam infra struktur itu yang nampak paling menonjol dan dominan adalah organisasi politik yang perwujudannya berupa partai politik. Supra struktural pada hakikatnya adalah berupa lembaga-lembaga negara yang lazim disebut pemerintahan negara yang melindungi segenap bangsa dan seluruh tumpah darah dan mewujudkan kesejahteraan umum, serta mencerdaskan kehidupan bangsa. ${ }^{10}$

\footnotetext{
${ }^{9}$ Eko Sugitario, "Definisi Partai Politik", Jurnal Yustika, Vol. 1 No. 2, Desember 1998, hlm. 77.

${ }^{10}$ Eko Sugitario, Jurnal Yustika, Vol. 10 Desember 2007, hlm. 232.
} 
Partai politik yang dimaksud mempunyai kedudukan secara nasional, yang berarti bahwa partai politik yang didirikan diakui eksistensinya. Perihal pendirian partai politik, partai politik didirikan dan dibentuk oleh paling sedikit 50 (lima puluh) orang warga negara Indonesia yang telah berusia 21 (dua puluh satu) tahun dengan akta notaris. Pendirian dan pembentukan Partai politik menyertakan 30\% (tiga puluh perseratus) keterwakilan perempuan. Akta notaris harus memuat $\mathrm{AD}$ dan ART serta kepengurusan Partai politik tingkat pusat. AD memuat paling sedikit asas dan ciri Partai politik; visi dan misi Partai politik; nama, lambang, dan tanda gambar Partai politik; tujuan dan fungsi Partai politik; organisasi, tempat kedudukan, dan pengambilan keputusan; kepengurusan Partai politik; peraturan dan keputusan Partai politik; pendidikan politik; dan keuangan Partai politik. Kepengurusan Partai politik tingkat pusat disusun dengan menyertakan paling rendah 30\% (tiga puluh perseratus) keterwakilan perempuan sebagaimana Pasal 2 UU Parpol. Pendirian partai politik tersebut harus didaftarkan. Partai politik harus didaftarkan ke Departemen untuk menjadi badan hukum. Untuk menjadi badan hukum, Partai politik harus mempunyai: akta notaris pendirian Partai politik; nama, lambang, atau tanda gambar yang tidak mempunyai persamaan pada pokoknya atau keseluruhannya dengan nama, lambang, atau tanda gambar yang telah dipakai secara sah oleh Partai politik lain sesuai dengan peraturan perundangundangan; kantor tetap; kepengurusan paling sedikit 60\% (enam puluh perseratus) dari jumlah provinsi, 50\% (lima puluh perseratus) dari jumlah kabupaten/kota pada setiap provinsi yang bersangkutan, dan $25 \%$ (dua puluh lima perseratus) dari jumlah kecamatan pada setiap kabupaten/kota pada daerah yang bersangkutan; dan memiliki rekening atas nama Partai politik sebagaimana Pasal 3 UU Parpol.

Partai politik yang didirikan dan akta pendiriannya telah didaftarkan tersebut mempunyai tujuan dan fungsí. Tujuan umum Partai politik adalah mewujudkan cita-cita nasional bangsa Indonesia sebagaimana dimaksud dalam Pembukaan Undang-Undang Dasar Negara Republik Indonesia Tahun 1945; menjaga dan memelihara keutuhan Negara Kesatuan Republik Indonesia; mengembangkan kehidupan demokrasi berdasarkan Pancasila dengan menjunjung tinggi kedaulatan 
rakyat dalam Negara Kesatuan Republik Indonesia; dan mewujudkan kesejahteraan bagi seluruh rakyat Indonesia. Tujuan khusus Partai politik adalah: meningkatkan partisipasi politik anggota dan masyarakat dalam rangka penyelenggaraan kegiatan politik dan pemerintahan; memperjuangkan cita-cita Partai politik dalam kehidupan bermasyarakat, berbangsa, dan bernegara; dan membangun etika dan budaya politik dalam kehidupan bermasyarakat, berbangsa, dan bernegara. Tujuan Partai politik diwujudkan secara konstitusional sebagaimana Pasal 10 UU Parpol. Di antara tujuan dari partai politik tersebut di atas satu di antaranya yaitu menjaga dan memelihara keutuhan Negara Kesatuan Republik Indonesia dengan memecahkan segala permasalahan yang terjadi yang biasanya disampaikan melalui demonstrasi yang dilakukan oleh warga masyarakat karena hak-haknya tidak mendapatkan perlindungan hukum.

Kewajiban partai politik disertakan pula mengenai fungsi dibentuknya partai politik. Di antara fungsi dibentuknya partai politik secara rinci diatur dalam Pasal 11 UU Parpol, yaitu memberikan pendidikan politik bagi anggota dan masyarakat luas agar menjadi warga negara Indonesia yang sadar akan hak dan kewajibannya dalam kehidupan bermasyarakat, berbangsa, dan bernegara; penciptaan iklim yang kondusif bagi persatuan dan kesatuan bangsa Indonesia untuk kesejahteraan masyarakat; penyerap, penghimpun, dan penyalur aspirasi politik masyarakat dalam merumuskan dan menetapkan kebijakan negara; partisipasi politik warga negara Indonesia; dan rekrutmen politik dalam proses pengisian jabatan politik melalui mekanisme demokrasi dengan memperhatikan kesetaraan dan keadilan gender. Fungsi Partai politik diwujudkan secara konstitusional. Di antara fungsi partai politik ialah penciptaan iklim yang kondusif bagi persatuan dan kesatuan bangsa Indonesia untuk kesejahteraan masyarakat; penyerap, penghimpun, dan penyalur aspirasi politik masyarakat dalam merumuskan dan menetapkan kebijakan negara. Hal ini berarti bahwa jika masyarakat yang diwakili tersebut ternyata mengadakan demonstrasi karena hak-haknya kurang mendapat perlindungan hukum dengan diundangkannya suatu peraturan perundangundangan berarti bahwa aspirasi masyarakat tersebut kurang mendapat tanggapan 
dari partai politik, sehingga partai politik harus bertanggung jawab atas keresahan masyarakat yang berujung mengadakan demonstrasi tersebut.

Partai politik menurut Pasal 12 UU Parpol berhak memperoleh perlakuan yang sama, sederajat, dan adil dari negara; mengatur dan mengurus rumah tangga organisasi secara mandiri; memperoleh hak cipta atas nama, lambang, dan tanda gambar Partai politik sesuai dengan peraturan perundang-undangan; ikut serta dalam pemilihan umum untuk memilih anggota Dewan Perwakilan Rakyat, sesuai dengan peraturan perundang-undangan; membentuk fraksi di tingkat Majelis Permusyawaratan Rakyat, Dewan Perwakilan Rakyat, sesuai dengan peraturan perundang-undangan; mengajukan calon untuk mengisi keanggotaan Dewan Perwakilan Rakyat dan Dewan Perwakilan Rakyat Daerah sesuai dengan peraturan perundang-undangan; mengusulkan pergantian antar waktu anggotanya di Dewan Perwakilan Rakyat dan Dewan Perwakilan Rakyat Daerah sesuai dengan peraturan perundang-undangan; mengusulkan pemberhentian anggotanya di Dewan Perwakilan Rakyat dan Dewan Perwakilan Rakyat Daerah sesuai dengan peraturan perundang-undangan; mengusulkan pasangan calon Presiden dan Wakil Presiden, calon Gubernur dan Wakil Gubernur, calon Bupati dan Wakil Bupati, serta calon Walikota dan Wakil Walikota sesuai dengan peraturan perundang-undangan; membentuk dan memiliki organisasi sayap Partai politik; dan memperoleh bantuan keuangan dari Anggaran Pendapatan dan Belanja Negara/Anggaran Pendapatan dan Belanja Daerah sesuai dengan peraturan perundang-undangan. Partai politik

Kewajiban Partai politik diatur dalam Pasal 13 UU Parpol di antaranya mengamalkan Pancasila, melaksanakan Undang-Undang Dasar Negara Republik Indonesia Tahun 1945, dan peraturan perundang-undangan; memelihara dan mempertahankan keutuhan Negara Kesatuan Republik Indonesia; berpartisipasi dalam pembangunan nasional; menjunjung tinggi supremasi hukum, demokrasi, dan hak asasi manusia; melakukan pendidikan politik dan menyalurkan aspirasi politik anggotanya; menyukseskan penyelenggaraan pemilihan umum; melakukan pendaftaran dan memelihara ketertiban data anggota; membuat pembukuan, memelihara daftar penyumbang dan jumlah sumbangan yang diterima, serta 
terbuka kepada masyarakat; menyampaikan laporan pertanggungjawaban penerimaan dan pengeluaran keuangan yang bersumber dari dana bantuan Anggaran Pendapatan dan Belanja Negara dan Anggaran Pendapatan dan Belanja Daerah secara berkala 1 (satu) tahun sekali kepada Pemerintah setelah diperiksa oleh Badan Pemeriksa Keuangan; memiliki rekening khusus dana kampanye pemilihan umum; dan menyosialisasikan program Partai politik kepada masyarakat.

Pada uraian sebelumnya telah disinggung bahwa salah satu hak Partai Politik yaitu ikut pemilihan umum dan mencalonkan anggota Dewan Perwaakilan Rakyat dalam pemilihan umum secara langsung. Oleh karena itu partai politik melakukan rekrutmen terhadap warga negara Indonesia untuk menjadi: anggota Partai politik; bakal calon anggota Dewan Perwakilan Rakyat dan Dewan Perwakilan Rakyat Daerah sesuai dengan Pasal 29 UU Parpol.

Melihat dari fungsi, hak dan kewajiban partai politik dengan dinamika dan perkembangan masyarakat yang majemuk menuntut peningkatan peran, fungsi, dan tanggung jawab Partai politik dalam kehidupan demokrasi secara konstitusional sebagai sarana partisipasi politik masyarakat dalam upaya mewujudkan cita-cita nasional bangsa Indonesia, menjaga dan memelihara keutuhan Negara Kesatuan Republik Indonesia, mengembangkan kehidupan demokrasi berdasarkan Pancasila sebagaimana termaktub dalam Pembukaan Undang-Undang Dasar Negara Republik Indonesia Tahun 1945 dengan menjunjung tinggi kedaulatan rakyat dalam Negara Kesatuan Republik Indonesia, dan mewujudkan kesejahteraan bagi seluruh rakyat Indonesia.

Pemilihan Umum adalah sarana pelaksanaan kedaulatan rakyat yang dilaksanakan secara langsung, umum, bebas, rahasia, jujur, dan adil dalam Negara Kesatuan Republik Indonesia berdasarkan Pancasila dan Undang-Undang Dasar Negara Republik Indonesia Tahun 1945. Pemilu Anggota Dewan Perwakilan Rakyat, adalah Pemilu untuk memilih anggota Dewan Perwakilan Rakyat, dalam Negara Kesatuan Republik Indonesia berdasarkan Pancasila dan Undang-Undang Dasar Negara Republik Indonesia Tahun 1945. Peserta Pemilu adalah Partai Politik untuk Pemilu anggota DPR, DPRD provinsi, dan DPRD kabupaten/kota 
dan perseorangan untuk Pemilu anggota DPD. Partai Politik Peserta Pemilu adalah Partai Politik yang telah memenuhi persyaratan sebagai Peserta Pemilu.

\section{PENUTUP}

1. Rakyat yang menyalurkan aspirasinya dengan mengadakan demonstrasi yang ditujukan kepada pemerintah tidak tepat dalam sistem demokrasi di Indonesia, dan seharusnya disalurkan melalui DPR, karena sebagaimana Pasal 71 huruf s UU No. 27 Tahun 2009 bahwa DPR mempunyai tugas dan wewenang di antaranya menyerap, menghimpun, menampung, dan menindaklanjuti aspirasi masyarakat jika dikaitkan dengan fungsi dari DPR yaitu fungsi legislasi, yang berhubungan dengan upaya menterjemahkan aspirasi masyarakat menjadi keputusan-keputusan politik yang nantinya dilaksanakan oleh pihak Eksekutif (pemerintah).

2. Partai politik sistem pemerintahan demokrasi di Indonesia dalam menangani demonstrasi yang ditujukan kepada pemerintahan sangat berperan, karena salah satu fungsi dari partai politik sebagaimana Pasal 11 UU Parpol, yaitu memberikan pendidikan politik bagi anggota dan masyarakat luas agar menjadi warga negara Indonesia yang sadar akan hak dan kewajibannya dalam kehidupan bermasyarakat, berbangsa, dan bernegara; dan penyerap, penghimpun, dan penyalur aspirasi politik masyarakat dalam merumuskan dan menetapkan kebijakan negara; partisipasi politik warga negara Indonesia.

3. Masyarakat jika melakukan demonstrasi tidak ditujukan kepada pemerintah, karena pemerintah sebagai pelaksana undang-undang. Undang-undang yang dimaksud merupakan hasil DPR untuk menampung dan menyalurkan aspirasi rakyat, sehingga jika aspirasi rakyat tidak tersalurkan, menjadi tanggung jawab DPR.

4. Hendaknya DPR mendidik masyarakat untuk berpolitik sesuai dengan fungsi anggota partai politik dan yang diusung oleh partai politik, agar memahami mengenai hak-hak masyarakat dan kewajibannya. 
Abraham Ferry Rosando, Peran dan Fungsi Partai ...

\section{DAFTAR PUSTAKA}

\section{Buku dan Jurnal:}

Effendi, Masyhur. 1994. Hak Asasi Manusia Dalam Hukum Nasional dan Internasional. Jakarta: Ghalia Indonesia.

Sunggono, Bambang dan Aries Hartanto. 2001. Bantuan Hukum dan Hak Asasi Manusia. Bandung: Mandar Maju.

Sugitario, Eko, Implementasi Hak Kodrat dalam Hukum Positif Hak-hak Asasi Manusia di Negara Hukum, Disampaikan Pada Rapat Terbuka Sernat Universitas Surabaya, 19 Juli 2003.

Sugitario, Eko, “Definisi Partai Politik”, Jurnal Yustika, Vol. 1 No. 2, Desember 1998.

\section{Perundang-undangan:}

Undang-Undang Dasar Negara Republik Indonesia 1945

Undang-Undang Nomor 39 Tahun 1999 tentang Hak Asasi Manusia

Undang-Undang Nomor 2 Tahun 2008 tentang Partai Politik

Undang-Undang Nomor 27 Tahun 2009 tentang MPR, DPR, DPD dan DPRD

Undang-Undang Nomor 2 Tahun 2011 tentang Perubahan atas Undang-Undang Nomor 2 Tahun 2008 tentang Partai Politik 